\title{
Omsorg som lönearbete - och som forskningsfält
}

\begin{abstract}
„Omsorgspersonal balanserar mellan två stup: en demokratisk princip, den som handlar om människors rätt att bestämma över sina liv och en omhändertagandets och ansvarstagandets princip, den som handlar om att människor inte fär ligga på gatan och dö.

Att värdera andras liv och försöka ändra dem skapar förtryck. Att läta var och en sköta sitt leder till att den starke vinner. Oftast. Gud förbjude, som sagt, en lösning på detta dilemma. " ${ }^{1}$
\end{abstract}

\section{ROSMARI ELIASSON}

En rubrik, som lite snävare avgränsar mitt tema, kunde vara: Om svårigheter att hålla det konfliktfyllda vid liv - i omsorgsarbete som i forskningspraktik.

Praktiskt omsorgsarbete och forskning om omsorg är förvisso två ganska olika praktiker. Men jag vill lyfta fram en konflikt där likartade grundläggande värden kan stå mot varandra i både omsorgen och forskningen.

Det konfliktfyllda blir mitt bindmedel, när jag först ger en inblick i det omsorgsarbete som vi i en forskargrupp under flera år studerat, ur olika vinklar - och därefter ger en antydan, på ett mer allmänt plan, om hur jag tycker att vi som

Rosmari Eliasson tillträdde en professur i socialt arebte $\mathrm{i}$ Lund våren 1993. Hon är sociolog och har tidigare arbetat som forskare på Skå och forskat om utvecklingstendenser inom psykiatrin. Under senare år har hon varit forskningsledare vid Äldrecentrum i Stockholm och leder nu i Lund ett SFR-finansierat forskningsprogram "Äldreomsorgens vardag och villkor". forskare kan och bör förhålla oss i en social vetenskap som exempelvis forskning i socialt arbete. (En formulering av det dilemma jag kommer att uppehålla mig vid i såväl omsorgens som forskningens praktik - finns i citatet ovan.)

Det som sedan 10 år varit mitt forskningsfält har vi definierat som wäldreomsorgens vardag och villkor ". ${ }^{2}$ I centrum av mitt forskningsfält finns alltså en vardagsverklighet där kroppens skröplighet gör oss människor allt mer beroende av andras hjälp. Och ett omsorgsarbete där det till helt övervägande del är kvinnor som ger

1. Citatet är hämtat från en av våra forskningsrapporter vid Äldrecentrum i Stockholm, Göran Oddbratts och Anders Petersens bok Rågaing till kärleken (s. 95 och 127).

${ }^{2}$ Resultat från olika projekt inom detta forskningsprogram redovisas exv i boken Egenheter och allmänheter. En antologi om omsorg och omsorgens villkor (Eliasson, red. 1992). 
hjälp i form av traditionella kvinnosysslor: hushålls-, vård- och omsorgsarbete.

Våra studier har hittills i första hand fokuserat den offentliga omsorg som berör flest gamla människor i Sverige, den sociala hemtjänsten. Det handlar om ett arbete som består i städning, matlagning, blöjbyten, tunga lyft. Däri och däromkring finns - om det vill sig väl: inlevelsefulla och kompetenta omsorgshandlingar av det mest skiftande slag, egenartade mänskliga relationer, och en ovanligt rik flora av livets dramatik och absurditeter.

Vi ville beskriva, synliggöra och försöka begripa denna - den avlönade - äldreomsorgens vardag. Och vi tog vår utgångspunkt i gamla människors och omsorgspersonalens erfarenheter och upplevelser. Men formuleringen "vardag och villkor" står för ambitionen att rikta blicken mot institutionella och samhälleliga strukturer i sökande efter svar på frågor om varför det är som det är och blir som det blir i denna vardag.

Med den amerikanske sociologen C. Wright Mills ord (i boken "Den Sociologiska visionen« från 1959) skulle jag kunna säga att vi såg som vår uppgift att försöka "översätta personliga bekymmer till allmänna problem«.

\section{Forskningsläget}

När vi började forska inom det här området fanns det mycket lite tidigare forskning vi kunde luta oss mot. Traditionell samhällsvetenskaplig forskning har negligerat och osynliggjort kvinnors hushållsoch omsorgsarbete. Och kvinnoforskningen hade då i stort sett bara hunnit upp- märksamma detta osynliggörande. $\mathrm{Nu}$, ett decennium senare, står begreppen omsorg och omsorgsarbete (care, caring och caring work) i centrum för en hel del forskning. Och frågan om själva definitionen av begreppet omsorg ligger ofta på bordet i kvinnovetenskapliga diskurser. Jag ska inte fördjupa mig i den frågan. Bara påpeka en komplexitet hos begreppet omsorg: att det inkluderar både en kvalitet i relationen mellan människor och själva utförandet av omsorgsarbete. $^{3}$

Tyvärr har det nog hittills varit så att diskussionerna om omsorg och omsorgsarbete i stor utsträckning stannat inom det kvinnovetenskapliga eller feministiska paradigmet. En annan olycklig "innestängningu är - som jag ser det - att omsorgen och dess kvaliteter i den feministiska diskursen kommit att inneslutas i kvinnors kropp. Omsorg definieras som till sitt väsen feminin - och begrepp som omsorgsrationalitet och omsorgsmoral blir till ideologiska redskap där det kvinnliga ställs mot det manliga, som det goda mot det onda.

Ser vi (allt) det (goda) som kommit att betecknas omsorgsrationalitet eller omsorgsmoral, som något naturgivet kvinnligt, drar det uppmärksamheten från omsorgsarbetets villkor. T.ex. frågan om under vilka betingelser det finns utrymme för kvinnor och andra människor att ut-

\footnotetext{
${ }^{3}$ Engelska språket klarar den distinktionen i uttrycken "caring aboutu som står för den känslomässiga dimensionen resp "caring for" som svarar mot vårt "ta hand om" - t.ex. disken eller medicinutdelningen. Huruvida de två betydelserna sammanfaller eller ej - i praktiken - är en empirisk fråga.
} 
föra ett omsorgsarbete där kvalitetsaspekten i ordet får jordmån och plats att utvecklas.

Det här var en kort antydan om de skäl jag ser för att inte låsa frågan om vad omsorg är till vårt biologiska eller sociala kön. I stället vill jag lyfta fram en mer "könlös" konflikt som jag ser som grundläggande i »omsorgens väsen« - en konflikt som är värd att betänka också i vår egen praktik som forskare inom det sociala området. ${ }^{4}$

\section{Ansvaret och respekten}

Om vi utgår från en helhetssyn på människan som både raktive i sin egen tillbli-

${ }^{4}$ Jag bygger här på en diskussion om "människosyn och moral" i boken Forskningsetik och perspektivval (Eliasson, 1987) velse, och som beroende av andra och sina livsbetingelser har vi att leva med:

å ena sidan respekten för den enskilda, unika människan, hennes självbestämmande och integritet och

å andra sidan det kollektiva och individuella ansvar vi människor har för varandra. I synnerhet då vad den danske filosofen Uffe Juul Jensen betecknat som en grundläggande princip i all moral, nämligen principen om vairt ansvar för de svaga i samhället. (Se figur nedan.)

Jag ser konflikten mellan dessa wheliga principer" som en "evig konflikt" - inneboende i välfärdsstaten och i själva det mänskliga samhället. Den kräver olika hantering i olika sammanhang - men det svåra är gemensamt: att hålla konflikten levande - att inte söka dess principiella lösning.

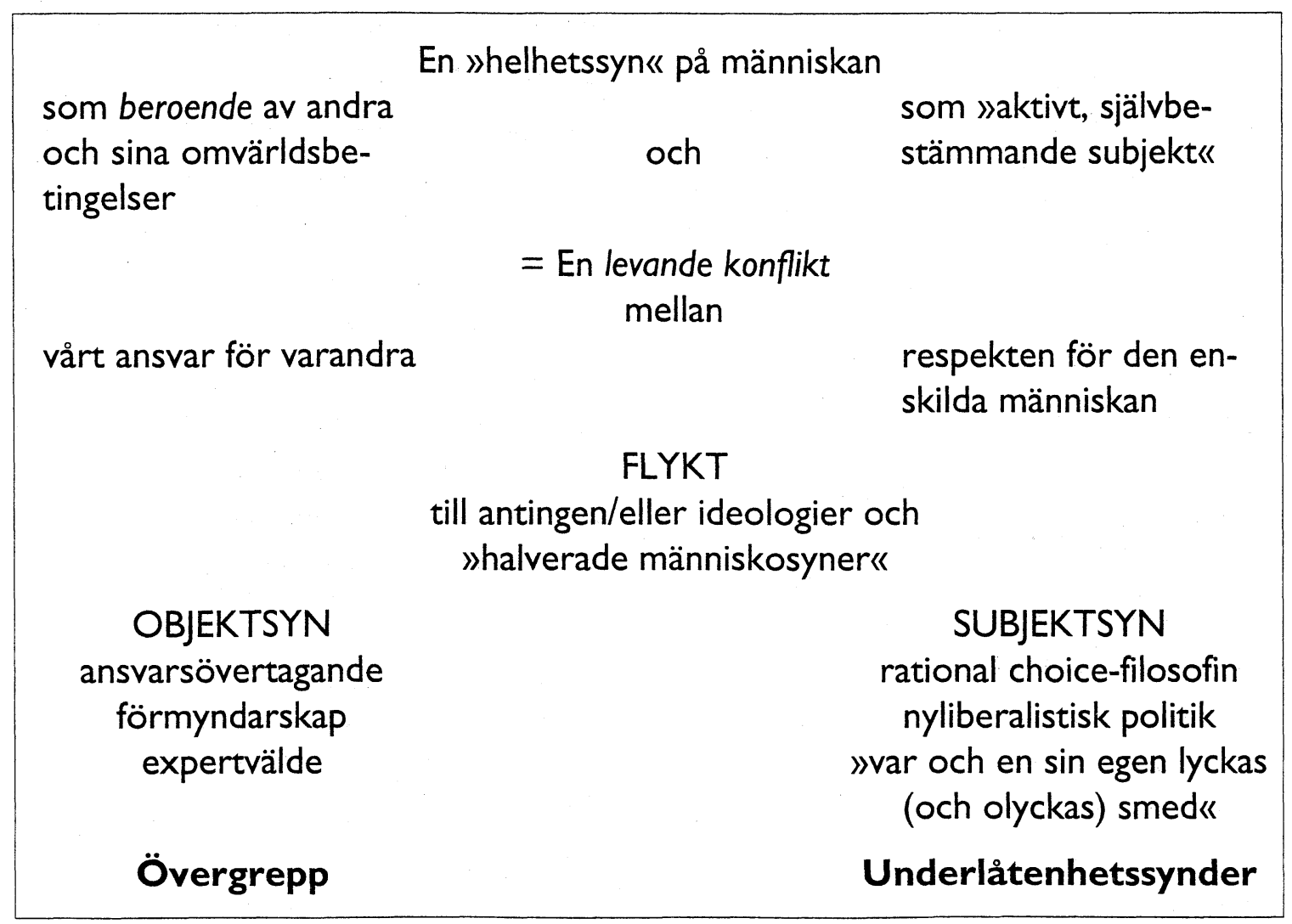


Sören Kierkegaard talar om det patetiskt komiska som ligger i att människan lever i ögonblicket, samtidigt som hon där - i ögonblicket - ska ta ställning för det eviga. Och visst - våra ställningstaganden i situationen - blir ofta både patetiska och komiska. Men inte desto mindre viktiga. Först:

\section{Ett exempel, från omsorgens vardag}

Under mina första försök att lära känna mitt forskningsområde gick jag som praktikant med olika vårdbiträden i hemtjänsten. En av dessa kvinnor, Sonja, beklagade sig över att det ibland kunde kännas hopplöst och lönlöst att städa hos en av sina pensionärer. Petterson söp sig regelmässigt full, stökade till och spydde rakt ut på golvet. Hos honom tydliggjordes i ovanligt hög grad det som kännetecknar det repetitiva hushållsarbetet, dess obeständighet. Eller som den norska sociologen Kari Wærness uttrycker den saken: "glädjen av en avtorkad /ryddet/ diskbänk är något mycket kortvarigtı.

Men, resonerade detta vårdbiträde, ungefär: supandet är ju hans sak, det är han som bestämmer över sitt liv. På mitt ansvar ligger att göra rent och snyggt i lägenheten - och därtill: jag tycker ju om honom, jag vill att han ska ha det drägligt omkring sig - även om den glädjen är mycket kortvarig. Så kom hon upphetsad och strålande en dag och hade att berätta: Kan du tänka dig vad som hänt! När jag kom dit idag, då hade han hittat sockerkaksformen - den med upphöjning i mitten - och spytt i den. För min skull, tror jag. Visst blir man glad när man ser en människa utvecklas.

I likhet med många andra i hemtjänsten hade Sonja klarat balansgången i den konflikt där man i motsättningens båda sidor dansar på slak lina:

- det ansvar man har och känner för att den gamla ska leva ett så drägligt liv som möjligt, kan lätt slå över i omyndigförklarande och förmyndarskap; bli till övergrepp på den gamles självbestämmande och integritet - och (på högersidan i figuren):

- respekten för den andres självbestämmande kan slå över i oengagemang och "underlåtenhetssynder" - att man inte bryr sig, låter människor svälta eller supa sig ihjäl - var och en betraktade som ansvariga för sitt liv.

Med begreppet flykt i figuren menar jag olika sätt att undfly konflikten, i anammande av antingen/eller-ideologier. Vi kan t.ex. med hänvisning till politisk ideologi, vårdideologi och professionella principer hävda att det enda rätta och riktiga är att betrakta och bemöta människor på antingen det ena eller det andra sättet.

\section{Och den pendeln svänger.....}

Inte bara i den svenska valfrihetsrevolution, utan också $i$ våra grannländer i öster, har pendeln på sistone tagit ut svängen ordentligt mellan motsättningens båda poler.

Medan välfärdsstaten och dess offentliga sektor under vårt sekel vuxit till sig har mycken samhällskritik (från både vänster och höger) skjutit in sig på statligt förmynderi och ansvarsövertagande. Idag tycks staten vara på väg att dra sig tillbaka 
såsom ansvarstagare. I politisk retorik växer sig individen och "hennes eget ansvar» större och starkare.

\section{Men:}

Parallellt med att pendeln i den politiska ideologin svängt mot en subjektifierande människosyn, med betoning av individens självbestämmande och valfrihet har vi i hemtjänsten - $i$ omsorgens vardag - sett pendeln svänga åt andra hållet. ${ }^{5}$ Bakom de vackra orden finner vi där - i praktiken utvecklingstendenser som drar mot en "objektifiering" där den gamles inflytande och självbestämmande minskar. Två sådana mycket tydliga förstörelseprocesser kan vi samla under begreppen taylorisering och professionalisering. Jag hårddrar:

Taylorisering av omsorgsarbetet innebär en sönderstyckning, uppifrån- och detaljstyrning av arbetet av samma slag som det löpande-bandets princip i industrin. En organisering av arbetet som i sin extrema form obönhörligt leder till ett förtingligande. Vårdbiträdena har att utföra de uppgifter som står på ett arbetskort. De tvingas behandla de gamla som "saker som ligger där" - och som ingenting har att säga till om. Personligt engagemang undviks också genom att vårdbiträdena sätts på rotation. De gamla blir i bokstavlig mening "föremål" för något som heter "äldreomsorg", men inte förtjänar sitt namn. Och Pettersson finner det förmodligen inte mödan värt att leta rätt på sockerkaksformen för någon vars namn han inte vet.

\footnotetext{
${ }^{5}$ Se exempelvis Marta Szebehely, 1992.
}

Den andra tendensen, som jag (i brist på bättre) kallar professionalisering (eller principstyrning) innebär också den en standardisering, där människor blir utbytbara: alla förväntas bete sig på samma sätt och alla ska behandlas lika. Det viktiga blir att följa (internaliserade) enhetliga principer, vilket gör att personalens tolk. ningsföreträde och makt ökar i förhållande till pensionären. Den gamles önskningar väger lätt mot principer som säger vad som är rätt och riktigt, ofta i namn av vad som bäst för den gamle. Att ha relativt kort tid kvar här på jorden ger med andra ord inte alltid något skydd för uppfostrande och människoförändrande ambitioner.

Även i vetenskapen kan vi finna exempel på tayloriseringstendenser. T.ex. i storskaliga, hierarkiskt uppbyggda "paraplyprojekt", där de stora tänker och andra utför, i en fragmenterad och hårt specialiserad forskning. Och tilltron till den enda rätta metoden är i vetenskapen inget nytt. Den dogmatismen kan - menar jag - vara lika snöpande i kunskapssökandet som i omsorgen. Därmed är vi framme vid frågan:

Hur ser konflikten mellan mansvaret och respekten" ut i vår egen verksamhet, som forskare?

\section{Forskningspraktiken}

Detta med att betrakta människor vi forskar om som objekt eller subjekt är ju en gammal fråga i vetenskapen. Här ska jag bara ta fasta på den motsättning som ofta yttrar sig som en fråga just om metodval, och om så kallade hårda eller mjuka data. 


\section{En "nyttighetsfälla"}

De forskare som anger den wsociala nyttanı som främsta argument för sin forskning hävdar vanligen - i linje med positivistiska vetenskapsideal - kvantitativa data och metoder som de enda Vetenskapliga; som själva grunden för det rationella tänkandet och handlandet. Därmed objektifieras oundvikligen dem vi forskar om, deras personliga bekymmer abstraheras till siffror i tabeller och stapeldiagram (utan att - såsom bekymmer - vare sig förstås eller förklaras).

Klär vi oss i den s.k. socialingenjörens kostym faller vi lätt i en "nyttighetsfälla", där vi fastnar i myndighets- och andra uppifrånperspektiv, snävar in kunskapssökandet till det åtgärdsrelevanta, till vad beslutsfattare och administratörer vill veta. Nyttofanatismen är ofta liktydigt med att, som någon uttryckt det, gå direkt wi tjänst hos generaler och socialarbetare, direktörer och fångvaktare». Där riskerar vi att förvandlas från forskare till experter - till någon som vet i stället för att förbli någon som vill veta. Om hörnet lurar, i vetenskaplig mundering, förmyndarmentaliteten.

\section{En "förtrogenhetsfälla"}

De som reser sig i protest mot det positivistiska paradigmet avvisar inte sällan allt vad hårda data och statistiska metoder heter. Under senare år är det kvinnoforskare som mest kraftfullt tagit ställning för kvalitativa metoder. Den argumentationen sker ofta i moraliska termer - kvalitativa metoder ses som garanti just för respekt för individen, subjekt-subjektrelationer, inlevelse och solidaritet med dem vi forskar om. "Hårda data" och statistiska metoder anses spegla en "manlig etik» och i sig vara förtryckande.

De forskare som dogmatiskt försvär sig till kvalitativa metoder har en tendens att dränka sig själva och sina läsare i fallbeskrivningar och livshistorier. Försjunker vi i denna "livets text " - löper vi risken att förlora den vetenskapens kritiska potential som ligger bl.a. i ambitionen att försöka översätta personliga bekymmer till allmänna problem. Kanske kan vi här tala om en "förtrogenhetsfälla» där vi inte ser skogen för bara trän.

Om vi t.ex. förkastar möjligheten att räkna på det som räknas kan begränsar vi, menar jag, inte bara vårt synfält och problemområde - utan avhänder oss redskap för social kritik. Hårda data och statistiska metoder behövs för att påvisa utbredning av onda förhållanden - och för att påvisa ojämlikhet och orättfärdigheter i sådant som fördelning av pengar och andra resurser, i samhällelig service, vård och omsorg. Men med enbart hårda data kan vi varken förstå eller förklara, och når inte långt utanför det redan på mer eller mindre säkra grunder kända.Vi måste ju bl.a. på förhand bestämma vad som är värt att veta.

Jag har här mycket grovt förenklat en motsättning som har sin grund i olika vetenskapliga tanketraditioner. Och den motsättningen är viktig att se och ta på allvar. Men den förytligade motsättningen mellan hårda och mjuka data, ser jag som hämmande och begränsande i själva kunskapssökandet. Och det jag velat tydliggöra är att principiella ställningstaganden för antingen kvantitativa eller kvalita- 
tiva metoder kan vara lika förödande i forskningsarbete som det är för omsorgens praktik, om det inte där finns utrymme för både det sociala ansvaret och respekten för individen, hennes egenheter och särart.

\section{Avslutningsvis:}

Som forskare i socialt arbete befinner vi oss mycket tydligt $i$ en skärningspunkt mellan utomvetenskapliga och inomvetenskapliga krav. I de "utomvetenskapliga styrfälten« är det t.ex. mycket sällan klienter som gör sig hörda med sina krav och förväntningar på forskningen. Vad som är "nyttigu forskning definieras m.a.o. rättså självklart uppifrån om vi inte ser upp. Detta är ett skäl till att vi som forskare måste värna om rätten att själva välja våra perspektiv och frågeställningar. Klarar vi att försvara den friheten, så bör vi också kunna avstå från att låta Metoden bestämma våra perspektiv och definiera möjliga frågor åt oss.

Den redan citerade C Wright Mills såg redan för drygt 35 år sedan det intellektuella hantverketı som hotat dels av samhällsvetenskapen byråkratiska anda och lakejmentalitet i förhållande till makten, dels av inomvetenskapliga inskränktheter och dumdrygheter. ${ }^{6}$

Ser vi som forskare vårt sociala ansvar, samtidigt som vi både vill bevara respekten för de människor vi forskar om och respekten för vårt eget arbete som kunskapssökande verksamhet, tror jag att det vi måste ta på

\footnotetext{
${ }^{6}$ I första hand retade Mills sig då på den abstraherade empirismens "metodologiska hämning" och den "fetishistiska dyrkan av Begreppetu hos dem som hävdar att de sitter inne med den generella teorin.
}

allvar och värna om är vårt kritiska mandat - ett mandat som omfattar såäl kritik av den sociala verkligheten som skepsis i förhållande till redan befintliga teorier och etablerade metoder.

Om vi sätter själva kunskapssökandet nyfikenheten och kritiken - före renlärighet och principfasthet när det gäller metoder får vi ta risken att betraktas som oprofessionella och lite gammelmodiga. På samma sätt som de vårdbiträden i hemtjänsten som ständigt bryter mot givna regler och principer i sin strävan att leva upp till sin uppgift och omsorgens specifika krav.

Därmed hoppas jag ha knutit ihop trådarna mellan omsorgens och forskningens praktik, och upprepar: Gud bevare oss från att finna en principiell lösning på våra dilemmor.

\section{Referenser}

Eliasson, Rosmari, red. (1992) Egenheter och allmänheter. En antologi om omsorg och omsorgens villkor, Lund: Arkiv.

Eliasson, Rosmari (1987) Forskningsetik och perspektivval, Lund: Studentlitteratur.

Juul Jensen, Uffe (1985) Moraliskt ansvar och människosyn, Lund: Studentlitteratur.

Kierkegaard, Sören (1977) Skrifter i urval, Stockholm:Wahlström \& Widstrand.

Mills, C. Wright (1971) Den sociologiska visionen, Stockholm: Prisma.

Odbratt, Göran \& Petersen, Anders (1991) Rågång till kärleken, Stockholm: Norstedts.

Szebehely, Marta (1992) "Vårdbiträdets vardag - i öppenvård och vid servicehus» och „PS om självstyrande grupper» i Eliasson, R. (red): Egenheter och allmänheter, Lund: Arkiv.

Wærness, Kari (1982) "Familjen" i Det Moderne Norge 2, Oslo: Gyldendal. 